\title{
К вопросу о понятиях «международное энергетическое право» и «энергетическое право ЕС»
}

\section{Смирнов Д.Л.*}

Статья представляет собой попытку раскрыть такие понятия, как «международное энергетическое право» и «энергетическое право ЕС». Автор полагает, что еще слишком рано говорить о формировании отдельной отрасли права или отдельной системе норм, представляющих собой международное энергетическое право или энергетическое право $\mathrm{EC}$, хотя основания для этого и могут появиться в дальнейшем с развитием договорно-правовой базы. На настоящем уровне развития норм энергетического права возможно говорить лишь о целесообразности исследований и преподавания международно-правовых аспектов регулирования энергетики как отдельной учебной дисциплины.

Ключевые слова: международное энергетическое право; энергетическое право ЕС (Европейского союза); право Европейских сообществ; право Европейского союза; европейское право; правовое регулирование энергетики.

Правоотношения между государствами в энергетической сфере начали складываться уже довольно давно, и такие отношения регулируются нормами международного договорного ${ }^{1}$ и обычного права ${ }^{2}$,

\footnotetext{
* Смирнов Дмитрий Львович - аспирант кафедры европейского права МГИМО (У) МИД России, старший юрист Коллегии адвокатов «Монастырский, Зюба, Степанов и Партнеры».ssmirnovdd@mail.ru.

1 О развитии источников международного права, распространяющегося на энергетику, - международных договоров и норм «мягкого» права, принимаемых по итогам международных встреч, конференций, а также деклараций или же рекомендаций, вырабатываемых международными организациями, см. подробнее, в частности: Основы международно-правового регулирования деятельности государств в сфере энергетики / Международное право: Учебник / Отв. ред. А.Н. Вылегжанин. М.: Высшее образование, Юрайт-Издат, 2009. § 27.10. Гл. 27. С. 985-1009; R. Lyster and A. Bradbrook. Energy Law and Environment. Cambridge University Press, 2006. Chapter 3; Вылегжанин А.Н. Недропользование: некоторые теоретические вопросы международного права // Московский журнал международного права. Спец. выпуск, декабрь 2005. С. 7-33.

2 O принципах (1) постоянного суверенитета государства в отношении природных ресурсов (2) непричинения ущерба территории другого государства или территорий вне пределов национальной юрисдикции; (3) обязанности уведомлять и сотрудничать
} 
а субъектами этих отношений выступают государства и международные организации как субъекты международного права 3 , обладающие нормотворческими правоспособностями.

В отношении нормотворческой правоспособности субъектов международного права проф. Г.М. Вельяминов отмечает, что « ...cyбъекты международного права наделены не только правомочиями заключать правоприменительные акты в рамках действующего международного права, но и правоустанавливающче акты, основывающчиеся на властных прерогативах, а именно творить нормы международного права посредством, в частности, заключения международных договоров...»" .

В последние три-четыре десятка лет правовое регулирование сотрудничества государств в такой значимой сфере экономических отношений между государствами, как энергетика, получило существенное развитие именно благодаря нормотворческой деятельности субъектов международного права, что позволило юристам-международникам все чаще рассматривать новый массив создаваемых правовых норм международного права, регулирующих такие отношения, как самостоятельную систему норм международного права, которая требует отдельного изучения. Появились различные двусторонние ${ }^{5}$ и многосторонние

с другими государствами в отношении рисков, связанных с использованием опасных веществ, см., например: I. Brownlie, Principles of Public International Law (6th edn., 2003); Вылегжанин А.Н. Недропользование: некоторые теоретические вопросы международного права. С. 7-33; Решение Международного суда ООН по делу Демократической Республики Конго против Уганды от 19 декабря 2005 г., Решение Международного суда ООН по делу о проливе Корфу 1949 г. - Corfu Channel case, Judgement of April 9th, 1949. I.C.J. Reports 1949.

3 В российской и зарубежной доктрине идет дискуссия относительно того, кто может выступать в роли субъекта международного права. См., например: Черниченко С.В. Еще раз о международной правосубъектности индивидов // Московский журнал международного права. № 4 (60). 2005. С. 11-26; Саяпин С.В. К вопросу о международной правосубъектности индивидов // Московский журнал международного права. № 4 (60). 2005. С. 27-38. Эта дискуссия носит совершенно самостоятельный характер, и внимания заслуживают все точки зрения, однако для целей настоящей работы автор придерживается традиционной концепции, согласно которой субъектами международного права являются государства и международные организации.

4 Вельяминов Г.М. Международное экономическое право и процесс (Академический курс). М.: Волтерс Клувер, 2004. С. 51.

5 Соглашение между Бахрейном и Саудовской Аравией 1958 г., Соглашение между Катаром и Объединенными Арабскими Эмиратами 1969 г., Соглашение между Великобританией и Норвегией о трансграничном сотрудничестве по вопросам нефтедобычи 1975 г. (в ред. от 4 апреля 2005 г.); Соглашение между Австралией и Папуа Новая Гвинея 1978 г.; Соглашение между Исландией и Норвегией 1981 г.; Соглашение 
договоры регионального ${ }^{6}$ и межрегионального значения ${ }^{7}$, а также договоры, учреждающие специальные международные организации ${ }^{8}$. Однако следует отметить, что до настоящего времени не существует универсального международного договора по вопросам энергетики.

Существенное развитие международного сотрудничества в области энергетики и возникновение в зарубежных источниках понятия «международное энергетическое право» ${ }^{9}$ связаны с энергетическим кризисом 1973 г. В 1960 г. нефтеэкспортирующие страны создали свою организацию - Организацию стран - экспортеров нефти (далее - ОПЕК ${ }^{10}$ ), ограничили поставки нефти, чтобы противостоять влиянию крупных транснациональных вертикально интегрированных ${ }^{11}$ нефтяных компаний, известных как «семь сестер» ${ }^{12}$. В дальнейшем это позволило арабским странам использовать нефть как «оружие» на Ближнем Востоке как в 1967-м, так и в 1973 г., что и вызвало кризис ${ }^{13}$. Конечно же, нельзя говорить, что до этого не существовало права, регулирующего производство

между Австралией и Индонезией 1989 г; Соглашение между Великобританией и Данией 1999 г.; Двустороннее соглашение об инвестициях между Великобританией и Венгрией от 1987 г., Соглашения России с Казахстаном (1998 г.) и Азербайджаном (2002 г.) о разграничении дна Каспийского моря в целях недропользования и др. - см. подробнее: Основы международно-правового регулирования деятельности государств в сфере энергетики / Международное право: Учебник / Отв. ред. А.Н. Вылегжанин. М.: Высшее образование, Юрайт-Издат, 2009. С. 988-999.

6 Амстердамский договор 1997 г., ОЈ С-340/01 (1997); Конвенция о защите морской среды обитания в Северо-Восточной части Атлантического океана от 1992 г. и др. логоразведки, добычи, транспортировки, переработки до продажи бензина на АЗС.

7 Женевские морские конвенции 1958 г., Конвенция по морскому праву 1982 г., Конвенция о биологическом разнообразии 1992 г., Рамочная конвенция ООН об изменении климата 1992 г.; Соглашение ГАТТ/ВТО от 1994 г., Договор к Энергетической хартии 1994 г. и др. - см. подробнее: Основы международно-правового регулирования деятельности государств в сфере энергетики / Международное право: Учебник / Отв. ред. А.Н. Вылегжанин. С. 988-999.

8 Договоры о создании ООН, ОПЕК, ОАПЕК, МЭА, Всемирной морской организации и др.

${ }^{9}$ International Energy Law / prepared by International Bar Association Section on Energy and Natural Resources Law - Houston: Matthew Bender \& Company Incorporated, 1984. 1490 p. 10 www.opec.org

11 Это компания или ее дочернее предприятие, которое контролирует все аспекты производства нефтепродуктов от геологоразведки, добычи, транспортировки, переработки до продажи бензина на АЗС.

12 A. Sampson. The Seven Sisters: the great oil companies and the world they made (1975). Эти компании: Gulf, Texaco, Mobil, Standard Oil (Chevron), Exxon, Shell, BP.

13 См.: Ергин Д. Добыча. Всемирная история борьбы за нефть, деньги и власть / Пер. с англ. 2-е изд. М.: Издательство «ДеНово», 2001. 
энергии. До 1970-х гг. можно говорить о существовании права нефти и газа (особенно в США) или права в области добычи полезных ископаемых (существовавшего на протяжении нескольких веков в Европе). Однако только с появлением необходимости обеспечить безопасность и диверсифицированность снабжения энергоресурсами можно говорить об энергетическом праве как о самостоятельной, охватывающей различные аспекты отрасли либо подотрасли международного экономического права. На национальном уровне были созданы министерства энергетики, а на международном уровне - Международное энергетическое агентство (МЭА) в 1974г. и иные международные организации.

Указанные межгосударственные (межправительственные) организации, являясь наряду с государствами субъектами международного права ${ }^{14}$, выступают субъектами международных правоотношений в энергетической сфере, обладают правами и обязанностями, в том числе и правом заключать международные соглашения. В настоящее время существуют как международные организации, непосредственно занимающиеся вопросами регулирования в энергетической сфере, - такие как Международное Агентство по атомной энергетике (МАГАТЭ) и упомянутые выше ОПЕК и МЭА, - так и международные организации, мандат которых позволяет им заниматься, в частности, и вопросами энергетики: Организация Объединенных Наций $(\mathrm{OOH})$, Всемирная торговая организация (ВТО), региональные организации - Североамериканская ассоциация свободной торговли (НАФТА), Ассоциация государств Юго-Восточной Азии (АСЕАН) и другие.

«...Юридические лица, прежде всего транснациональные корпорации, так же как и физические лища, не обладают международной правосубъектностью...»15. Однако в зарубежной литературе существует мнение, что в энергетической сфере, как и в других сферах, в настоящее время круг участников международных правоотношений расширяется и становится более разнообразным: помимо государств и международных организаций в него входят транснациональные корпорации, неправительственные международные организации, а также физические лица ${ }^{16}$. Действительно, с развитием международного сообщества вовлеченность других, негосударственных участников в международную

${ }^{14}$ Международное право: Учебник / Отв. ред. А.Н. Вылегжанин. С. 136-137.

15 Там же. C. 138.

${ }^{16}$ Energy Law in Europe. National, EU, and International Regulation. Edited by M. Roggenkamp, C. Redgwell, I. del Guayo, and A. Ronne. Oxford University Press, 2007. P. 16. 
жизнь и международную правовую систему возрастает. В энергетической сфере функции по разработке и эксплуатации месторождений природных ресурсов, а также их переработке, транспортировке через государственные границы, перераспределению между государствами в значительной степени взяли на себя национальные и международные корпорации. Указанная деятельность зачастую выходит за рамки национального регулирования и подпадает под действие норм международного права. Можно с уверенностью говорить о возрастающей роли юридических и физических лиц в статусе либо участников, либо субъектов международного права с особенными, отличными от государств и межправительственных организаций правами и обязанностями (ограниченной международной правосубъектностью) ${ }^{17}$. Несмотря на то что эти участники не могут быть признаны субъектами международного права, влияние их деятельности на международные отношения, в частности в энергетической сфере, нельзя недооценивать ${ }^{18}$.

Увеличивающееся экономическое значение международных энергетических связей и необходимость правового регулирования в этой области, неуклонно возраставшая в последние десятилетия, позволила ряду ученых говорить о международном энергетическом праве как об отдельной подотрасли международного экономического права. «... С начала 1990-х г2. именно такая отрасль международного права, как международное экономическое право, очутимо приросла «энергетическим» компонентом» ${ }^{19}$.

Тем не менее в международно-правовой науке понятие «международное энергетическое право» пока не получило общего признания как отдельная отрасль права или подотрасль международного права. Существует мнение о том, что вопросы международной энергетики в настоящее время следует рассматривать в рамках права международных организаций и международного экономического права ${ }^{20}$.

17 Op. cit. Р. 23.

18 В зарубежной литературе была выдвинута концепция транснационального права. См.: Шумилов В.М. Международное публичное экономическое право: Учебное пособие. М.: НИМП, 2001. С. 68-70.

19 Международно-правовые основы недропользования: Учеб. пособие / Отв.ред. А.Н. Вылегжанин. С. 45. См. также: Международное право / Отв. ред. Ю.М. Колосов, Э.С. Кривчикова. М., 2005. С. 737-756; Вылегжанин А.Н. Недропользование: некоторые теоретические вопросы международного права. С. 10.

20 Международно-правовые основы недропользования: Учеб. пособие / Отв.ред. А.Н. Вылегжанин. С. 41; Вылегжанин А.Н. Недропользование: некоторые теоретические вопросы международного права. С. 11. 
Действительно, международная деятельность в сфере энергетики регулируется не только нормами международного экономического права, но и широким спектром норм других отраслей международного права, относящихся к регулированию как энергетики, так и других сфер деятельности ${ }^{21}$. Деятельность международных организаций, занимающихся вопросами энергетики, таких как ОПЕК, МЭА, Евратом, Европейское сообщество (ныне Евросоюз), Европейская ассоциация свободной торговли, Организация экономического сотрудничества и развития (ОЭСР), МАГАТЭ, Европейская экономическая комиссия (ЕЭК) как специализированное подразделение Экономического и Социального совета ООН, традиционно рассматривается в рамках изучения права международных организаций, а правовые вопросы энергетики, которыми, в частности, занимаются указанные международные организации, - в рамках международного экономического права 22.

Действительно, «... то, что значительная часть комплекса международно-правовых норм о недропользовании тяготеет к международному экономическому праву, не означает монополии последнего на регулирование отношений государств в сфере недропользования. Понятно, что в зависимости от конкретного объекта регулирования к таким отношениям применимы, в соответствующих ситуациях, нормы других отраслей международного права: морского (в случае разработок недр континентального шельфа, например); права окружающей среды (практически во всех случаях); космического (в случае разработки недр Луньь ${ }^{23}$, к примеру) $и$ т.д. ...» ${ }^{24}$.

Таким образом, в настоящее время нормы международного права, регулирующие, в частности, и энергетику, не представляют собой отдельной системы норм, поэтому целесообразным было бы говорить

${ }^{21}$ Energy Law in Europe. National, EU, and International Regulation. Edited by M. Roggenkamp, C. Redgwell, I. del Guayo, and A. Ronne. Oxford University Press, 2007. P. 16.

22 Там же. Р. 41.

23 О правовом режиме природных ресурсов Луны и других небесных тел см. подробнее: Колосов Ю.М. Правовой режим природных ресурсов Луны и других небесных тел // Международно-правовые основы недропользования: Учеб. пособие / Отв. ред. А.Н. Вылегжанин; [авт. предисл. А.В. Торкунов]. М.: Норма, 2007. § 3 гл. 9. С. 237-242; Смирнов Д.Л. Освоение космоса и энергетические природные ресурсы: международно-правовое регулирование // Московский журнал международного права. 2006. № 3. C. 104-123.

24 Международно-правовые основы недропользования: Учеб. пособие / Отв. ред. А.Н. Вылегжанин; [авт. предисл. А.В. Торкунов]. С. 51. 
о нормах международного права, относящихся к регулированию в этой сфере. Между тем понятие «международное энергетическое право» и международное энергетическое право как академическая дисциплина, получившее развитие в европейских странах, справедливо отражают международный характер деятельности в энергетической сфере, выходящий за рамки регулирования национальными государствами.

Как справедливо отмечают д.ю.н., проф. А.Н. Вылегжанин в коллективном труде «Международно-правовые основы недропользования» 25 , подготовленном коллективом авторов кафедры международного права МГИМО (У) МИД России на основе опыта преподавания специального курса «Международно-правовые основы недропользования», а также д.ю.н. А.В. Яковенко, д.ю.н. Д.К. Лабин и д.ю.н. Е.Е. Андреева в коллективном труде «Международное право» 26 , подготовленном кафедрой международного права МГИМО (У) МИД России под редакцией А.Н. Вылегжанина: «... С учетом экономического значения нефтегазовых , угольныхх и иных природных ресурсов, обеспечиваючих энергетику, и растущзего сотрудничества государств в этой области в юридической литературе иногда говорится о начале формирования международного энергетического права в качестве подотрасли межсуннародного экономического права. Хотя договорно-правовых подтверждений в пользу такого подхода в настоящее время пока нет, они <..> могут появиться в будущем...».

Автор настоящей статьи солидарен с подходом международно-правой школы МГИМО (У) МИД России и зарубежных авторов, которые полагают, что пока рано говорить о появлении международного энергетического права и «...можно лишь говорить о целесообразности исследований и преподавания < .. > межсдународно-правовых аспектов энергетики...» ${ }^{27}$ в качестве отдельной учебной дисциплины ${ }^{28}$.

В связи со всем вышеизложенным очевидно, что правоотношения, которые складываются между государствами - членами Европейского союза в энергетической сфере, также регулируются международно-правовыми нормами различных отраслей международного права.

25 Там же. С. 47.

26 Международное право: Учебник / Отв. ред. А.Н. Вылегжанин. С. 988.

27 Международно-правовые основы недропользования: Учеб. пособие / Отв. ред. А.Н. Вылегжанин; [авт. предисл. А.В. Торкунов]. С. 41.

28 Bradbrook A.J. Energy Law as an Academic Discipline. 1996. 14:2 JERL 194, 206. 
Право ЕС или европейское право - это часть международного права ${ }^{29}$. Многие авторы при рассмотрении различных аспектов европейского права анализировали его природу и природу самих Европейских сообществ. Среди них особо следует выделить тот вклад, который внесли в дискуссию отечественные авторы: М.М. Бирюков $^{30}$, С.Ю. Кашкин ${ }^{31}$, А.Я. Капустин ${ }^{32}$, Ю.М. Колосов ${ }^{33}$, Э.С. Кривчикова ${ }^{34}$, Г.П. Толстопятенко ${ }^{35}$, Б.Н. Топорнин ${ }^{36}$, Н.Б. Шеленкова ${ }^{37}$, В.М. Шумилов ${ }^{38}$, Л.М.Энтин ${ }^{39}$, М.Л. Энтин ${ }^{40}$, а также зарубежные уче-

${ }^{29}$ См. подробнее об этом: Бирюков М.М. Европейская интеграция: международноправовой подход. Монография. М.: Научная книга, 2004. 208 с.; Бирюков М.М. Европейское право: Курс лекций. М.: Омега-Л, 2006. 128 с. (Библиотека высшей школы); Бирюков М.М. Европейский союз, евроконституция и международное право. М.: Научная книга, 2006. 256 с.; Капустин А.Я. Европейский Союз: интеграция и право. М.: Изд-во РУДН, 2000; Международное право: Учебник / Отв. ред. Ю.М. Колосов, Э.С. Кривчикова. 2-е изд., перераб. и доп. М.: Международные отношения, ЮрайтИздат, 2007. 816 с.; Международное право: Учебник / Отв. ред. А.Н. Вылегжанин. ${ }^{30}$ Бирюков М.М. Европейское право до и после Лиссабонского договора. М.: Научная книга, 2010. 240 с.; Бирюков М.М. Европейская интеграция: международно-правовой подход. Монография. М.: Научная книга, 2004. 208 с.; Бирюков М.М. Европейское право: Курс лекций. 128 с. (Библиотека высшей школы); Бирюков М.М. Европейский союз, евроконституция и международное право.

${ }^{31}$ Право Европейского Союза: Учеб. пособие / С.Ю. Кашкин [и др.]; отв.ред.С.Ю. Кашкин. М.: Проспект, 2009. 304 с.; Право Европейского союза: Учебник для вузов / Под ред. С.Ю. Кашкина. М.: Юристъ, 2002. 925 с.

32 Капустин А.Я. Европейский Союз: интеграция и право. М.: Изд-во РУДН, 2000; Право Европейского Союза: правовое регулирование торгового оборота / Под. ред. В.В. Безбаха, А.Я. Капустина, В.К. Пучинского. М., 1999.

${ }_{33}$ Международное право: Учебник / Отв. ред. Ю.М. Колосов, Э.С. Кривчикова.

${ }^{34}$ Кривчикова Э.С., Анодина Т.Г. Региональные международные организации // Международное право: Учебник / Отв. ред. А.Н. Вылегжанин. М.: Высшее образование, Юрайт-Издат, 2009. 1012 с. Гл.13. С. 358-454; Международное право: Учебник / Отв. ред. Ю.М. Колосов, Э.С. Кривчикова.

35 Толстопятенко Г.П. Европейское налоговое право. Сравнительно-правовое исследование. М.: НОРМА, 2001.

36 Топорнин Б.Н. Европейское право: Учебник. М.: Юристъ, 1998.

${ }^{37}$ Шеленкова Н.Б. Европейская интеграция: политика и право. М., 2003.

${ }^{38}$ Шумилов В.М. Международное экономическое право в эпоху глобализации. М., 2003.

39 Европейское право: Учебник / Под. ред. проф. Л.М. Энтина. М., 2000; Европейское право. Право Европейского Союза и правовое обеспечение защиты прав человека: Учебник для вузов / Рук. авт. колл. и отв. ред. д.ю.н., проф. Л.М. Энтин. 2-е изд., пересмотр. и доп. М.: Норма, 2005. 960 с.

40 Европейское право. Право Европейского Союза и правовое обеспечение защиты прав человека: Учебник для вузов / Рук. авт. колл. и отв. ред. д.ю.н., проф. Л.М. Энтин. 
ные: Г. Бурка (G. Burca) ${ }^{41}$, П. Крейг (P. Craig) ${ }^{42}$, К. Ипсен (K. Ipsen $)^{43}$, T. Хартли (Т.C. Hartley) ${ }^{44}$, Т. Опперман (T. Oppermann) ${ }^{45}$, Р. Штрайнц (R. Streinz) $)^{46}$, Э. Эллис (E. Ellis) ${ }^{47}$, Т. Тридимас (T. Tridimas) ${ }^{48}$.

В частности, в настоящей статье автор солидаризируется с мнением проф. М.М. Бирюкова, который в своих работах под понятием «европейское право» имеет в виду совокупность правовых норм, регулирующих взаимоотношения, складывающиеся в рамках европейских интеграционных объединений, таких как Европейские сообщества (право сообществ), Европейский союз (общая внешняя политика и политика безопасности, а также сотрудничество полиций и судов в уголовно-правовой сфере) и в определенной степени Совет Европы (положения Европейской конвенции о защите прав человека и основных свобод 1950 г. $)^{49}$. Следует отметить, что в целом аналогичное определение было предложено проф. Л.М. Энтиным, который определил европейское право как «...систему юридических норм, создаваемых в связи с образованием и функционированием Европейских сообществ и Европейского союза и действующих и применяемых в пределах их юрисдикции на основе и в соответствии с учредительными договорами и общиими принципами права...»50, и проф. Г.П. Толстопятенко, который в своей монографии «Европейское налоговое право» под европейским правом понимал «...систему юридических норм, создаваемых в связи с образованием и функционированием Европейских сообществ и Европейского союза, действующих и применяемых на основе и в соответствии с учредительньми договорами и общими принщипами права...» ${ }^{51}$.

${ }^{41}$ Craig P., de Burca G. EU Law. Text, Cases and Materials. 3d ed. Oxford, 2003.

${ }^{42}$ Craig P., de Burca G. EU Law. Text, Cases and Materials. 3d ed. Oxford, 2003.

${ }^{43}$ Ipsen K. Voelkerrecht. - Muenchen: C.H. Beck, 1999.

${ }^{44}$ Хартли Т.К. Основы права Европейского сообщества. Введение в конституционное и административное право Европейского сообщества. Пер. с англ. / Науч.ред. В.Г. Бенды. М.: ЮНИТИ, 1998.

${ }^{45}$ Oppermann T. Europarecht. - Muenchen: C.H. Beck Verlag, 1999.

${ }^{46}$ Strainz R. Europarecht. Heidelberg, 1999.

${ }^{47}$ Ellis E. Public Law of the European Community / E. Ellis, T. Tridimas - London, 1995. ${ }^{48}$ Ellis E. Public Law of the European Community / E. Ellis, T. Tridimas - London, 1995.

${ }^{49}$ См., например: Бирюков М.М. Европейское право до и после Лиссабонского договора. С. 65-75; Бирюков М.М. Европейская интеграция: международно-правовой подход. С. 16-17; Бирюков М.М. Европейское право: Курс лекций. С. 40-44.

${ }^{50}$ Европейское право: Учебник / Под. ред. проф. Л.М. Энтина. М., 2000. С. 43.

51 Толстопятенко Г.П. Европейское налоговое право. Сравнительно-правовое исследование. М.: НОРМА, 2001. С. 11. 
Понятие «право Европейских сообществ» или «право Европейского сообщества», сокращенно - «право ЕС», используется для обозначения системы правовых норм, созданных первоначально в рамках трех сообществ (Европейского объединения угля и стали (ЕОУС), Европейского сообщества по атомной энергии (Евратома) и Европейского экономического сообщества (ЕЭС)) и продолжающих развиваться в рамках Европейского сообщества, под которым понимается собственно Европейское сообщество, в которое Договором о Европейском союзе от 1992 г. (Маастрихсткий договор) было преобразовано ЕЭС. ЕОУС было ликвидировано в 2002 г. Его компетенция, права, обязанности и имущество были переданы Европейскому сообществу. Указанная система правовых норм составляла так называемую «первую опору» права Европейского союза (европейского права) и включала в себя учредительные договоры и нормы, созданные институтами Европейских сообществ, которые подпадали под юрисдикцию Суда Европейских сообществ.

До Лиссабонского договора под термином «право Европейского союза» понимается уже более широкая система норм, включающая в себя право Европейских сообществ (первую опору), а также нормы, вырабатываемые в рамках так называемых второй и третьей опор Европейского союза, а именно: общая внешняя политика и политика безопасности, а также сотрудничество полиций и судов в уголовно-правовой сфере. Термин «право Европейского союза» используется как синоним термина «европейское право» 52 .

Правоотношения между государствами в сфере энергетики в рамках Европейского сообщества некоторые авторы по аналогии с «международным энергетическим правом» называют «энергетическим правом ЕС», которое иногда выделяют также в качестве отрасли права ЕС. Так, проф. М.М. Бирюков считает, что постепенно, «... в связи с процессами интегращии и передачи ряда национальных полномочий в ведение институтов Европейского союза, оно начинает включать ряд отраслей, отличающихся по содержанию от сходных по названию отраслей внутригосударственного права, - институциональное, таможенное, финансовое, налоговое, банковское, торговое право, право конкуренции и ряд других...» ${ }^{53}$. На формирование таких отраслей права ЕС, в частности, указывает и проф. Л.М. Энтин: «...nод европей-

52 Бирюков М.М. Европейское право до и после Лиссабонского договора. 73-75.

53 Бирюков М.М. Европейский союз, евроконституция и международное право. С. 32. 
ским правом понимается особая правовая система, охватывающая правовые установления европейской системы зашиты прав человека и европейское интеграционное право, регулирующее взаимоотношения, складывающиеся в прочессе европейской интегращии. Последнее включает <...> право Европейских сообществ и право Европейского союза, а равно отрасли права, формирующиеся в процессе становления и эволюции европейских интеграционных образований ...» ${ }^{54}$.

Тем не менее в связи со всем вышеизложенным, так же как и в случае с «международным энергетическим правом», автор полагает, что рано говорить о формировании какой-либо отдельной отрасли права или отдельной системы норм, такой как «энергетическое право ЕС», хотя основания для этого и могут появиться в дальнейшем с развитием договорно-правовой базы. На настоящем уровне развития «энергетического права» возможно говорить лишь о целесообразности исследований и преподавания международно-правовых аспектов энергетики в рамках ЕС как отдельной учебной дисциплины.

\section{Библиографический список:}

Бирюков М.М. Европейская интеграция: международно-правовой подход. - М.: Научная книга, 2004. - 208 с.

Бирюков М.М. Европейское право до и после Лиссабонского договора. - М.: Научная книга, 2010. - 240 с.

Бирюков М.М. Европейское право: Курс лекций. - М.: Омега-Л, 2006. - 128 с. - (Библиотека высшей школы).

Бирюков М.М. Европейский союз, евроконституция и международное право. - М.: Научная книга, 2006. - 256 с.

Вельяминов Г.М. Международное экономическое право и процесс (Академический курс) - М.: Волтерс Клувер, 2004.

Вылегжанин А.Н. Недропользование: некоторые теоретические вопросы международного права // Московский журнал международного права. Специальный выпуск, декабрь 2005. С. 7-33.

Европейское право: Учебник / Под. ред. проф. Л.М. Энтина. - М., 2000.

Европейское право. Право Европейского Союза и правовое обеспечение защиты прав человека: Учебник для вузов / Рук. авт. колл.

\footnotetext{
${ }^{54}$ Европейское право. Право Европейского Союза и правовое обеспечение защиты прав человека: Учебник для вузов / Рук. авт. колл. и отв. ред. д.ю.н., проф. Л.М. Энтин. С. 3.
} 
и отв. ред. д.ю.н., проф. Л.М. Энтин. - 2-е изд., пересмотр. и доп. - М.: Норма, 2005. - 960 с.

Ергин Д. Добыча. Всемирная история борьбы за нефть, деньги и власть / Пер. с англ. - 2-е изд. - М.: Издательство «ДеНово», 2001.

Капустин А.Я. Европейский Союз: интеграция и право. - М.: Издво РУДН, 2000.

Колосов Ю.М. Правовой режим природных ресурсов Луны и других небесных тел: Международно-правовые основы недропользования: Учеб. пособие / Отв. ред. А.Н. Вылегжанин; [авт. предисл. А.В. Торкунов]. - М.: Норма, 2007. § 3 гл. 9. С. 237-242.

Кривчикова Э.С., Анодина Т.Г. Региональные международные организации / Международное право: Учебник / Отв. ред. А.Н. Вылегжанин. - М.: Высшее образование, Юрайт-Издат, 2009. - 1012с. Гл. 13. C. 358-454.

Международное право: Учебник / Отв. ред. Ю.М. Колосов, Э.С. Кривчикова. - 2-е изд., перераб. и доп. - М.: Международные отношения, Юрайт-Издат, 2007. - 816 с.

Международное право / Отв. ред. Ю.М. Колосов, Э.С. Кривчикова. М.: 2005.

Международное право: Учебник / Отв. ред. А.Н. Вылегжанин. М.: Высшее образование, Юрайт-Издат, 2009.

Международно-правовые основы недропользования: Учеб. пособие / Отв. ред. А.Н. Вылегжанин; [авт. предисл. А.В. Торкунов]. - М.: Норма, 2007.

Основы международно-правового регулирования деятельности государств в сфере энергетики / Международное право: Учебник / Отв. ред. А.Н. Вылегжанин. - М.: Высшее образование, Юрайт-Издат, 2009.

Право Европейского Союза: правовое регулирование торгового оборота / Под. ред. В.В. Безбаха, А.Я. Капустина, В.К. Пучинского. M., 1999.

Право Европейского союза: Учебник для вузов / Под ред. С.Ю. Кашкина. - М.: Юристъ, 2002. - 925 с.

Право Европейского Союза: Учеб. пособие / С.Ю. Кашкин [и др.]; отв. ред. С.Ю. Кашкин. - М.: Проспект, 2009. - 304 с.

Саяпин С.В. К вопросу о международной правосубъектности индивидов // Московский журнал международного права. - № 4 (60) 2005. - С. 27-38. 
Смирнов Д.Л. Освоение космоса и энергетические природные ресурсы: международно-правовое регулирование // Московский журнал международного права. - 2006. - № 3. - С. 104-123.

Толстопятенко Г.П. Европейское налоговое право. Сравнительноправовое исследование. - М.: НОРМА, 2001.

Топорнин Б.Н. Европейское право: Учебник. - М.: Юристъ, 1998.

Черниченко С.В. Еще раз о международной правосубъектности индивидов // Московский журнал международного права. - №4 (60). - 2005. - C. 11-26;

Хартли Т.К. Основы права Европейского сообщества. Введение в конституционное и административное право Европейского сообщества. Пер. с англ. / Науч. ред. В.Г.Бенды. - М.: ЮНИТИ, 1998.

Шеленкова Н.Б. Европейская интеграция: политика и право. - М., 2003.

Шумилов В.М. Международное публичное экономическое право: Учебное пособие. - М.: НИМП, 2001. - С. 68-70.

Шумилов В.М. Международное экономическое право в эпоху глобализации. - М., 2003.

Bradbrook A.J. Energy Law as an Academic Discipline. 1996. 14:2 JERL 194, 206.

Brownlie I., Principles of Public International Law (6th edn., 2003).

Craig P., de Burca G. EU Law. Text, Cases and Materials. 3d ed. Oxford, 2003.

Ellis E. Public Law of the European Community / E. Ellis, T. Tridimas - London, 1995.

Energy Law in Europe. National, EU, and International Regulation. Edited by M. Roggenkamp, C. Redgwell, I. del Guayo, and A. Ronne. Oxford University Press, 2007.

International Energy Law / prepared by International Bar Association Section on Energy and Natural Resources Law - Houston: Matthew Bender \& Company Incorporated, 1984. - $1490 \mathrm{p}$.

Ipsen K. Voelkerrecht. - Muenchen: C.H. Beck, 1999.

Lyster R. and Bradbrook A., Energy Law and Environment. Cambridge University Press, 2006.

Oppermann T. Europarecht. - Muenchen: C.H. Beck Verlag, 1999. 


\section{To the Issue of Definitions of "International Energy Law" and "Energy Law of the European Communities" (Summary)}

\section{Dmitry L. Smirnov*}

The article appears to be an attempt to decipher such notions as "International Energy Law" and "Energy Law of the European Communities". The author considers it is too early to speak about a separate branch of law or separate system of legal norm as International Energy Law or Energy Law of the European Communities, although they could appear in the future following further development of the international treaties in the energy sphere. At the modern stage it could be useful to study and teach "international and EC energy law" as a separate academic discipline.

Keywords: International Energy Law; EC Energy Law (Energy Law of the European Communities); EC Law; EU Law; European Law; energy regulation.

* Dmitry L. Smirnov - Ph.D. student of the Chair of European law, MGIMO-University MFA Russia; senior lawyer of the "Monastyrsky, Zyuba Stepanov and Partners" law firm. ssmirnovdd@mail.ru. 